\title{
Production and efficiency of water usage in capsicum crops under no- tillage and conventional planting systems ${ }^{1}$
}

\author{
Produção e eficiência do uso da água na cultura do pimentão nos sistemas de plantio \\ direto e convencional
}

\author{
Maria Eliani Holanda Coelho ${ }^{2 *}$, Francisco Cláudio Lopes de Freitas ${ }^{3}$, Jorge Luiz Xavier Lins Cunha ${ }^{4}$, José \\ Francismar de Medeiros ${ }^{3}$ e Márcio Gledson Oliveira da Silva ${ }^{3}$
}

\begin{abstract}
This study aimed to evaluate the effect of no-tillage and conventional planting systems, and of weedmanagement strategies on water-usage efficiency in capsicum crops. The experiment was carried out at the Universidade Federal Rural do Semi-Árido in Mossoró, Rio Grande do Norte, using a split-plot layout in a randomized block design with four replications. The tillage systems were evaluated in the plots, and three weed-management strategies evaluated in the subplots (soil cover with polyethylene film, and with and without weeds). The density and dry mass of the weeds, the commercial and total productivity, and the daily water consumption were all evaluated. It was found that the no-tillage system reduced the density and dry mass of the weeds in comparison to conventional systems, and the interference of these plants reduced commercial productivity under both planting systems. The strategy of weeds under a no-tillage system, despite a higher water consumption, showed a productivity and efficiency of water usage superior to those of the strategies of polyethylene film both under no-tillage and conventional systems, and of weeds under a conventional tillage system.
\end{abstract}

Key words: Chili. Plant and water. Mulch. Weed control.

RESUMO - Objetivou-se avaliar o efeito dos sistemas de plantio direto e convencional e as estratégias de manejo de plantas daninhas na eficiência do uso da água pela cultura do pimentão. O experimento foi conduzido na Universidade Federal Rural do Semi-Árido, em Mossoró-RN, utilizando o esquema de parcelas subdivididas, no delineamento experimental em blocos casualizados, com quatro repetições. Os sistemas de plantio foram avaliados nas parcelas, e nas subparcelas três estratégias de manejo de plantas daninhas (cobertura do solo com filme de polietileno, capinado e sem capinas). Avaliou-se a densidade e massa seca das plantas daninhas, a produtividade comercial, total e o consumo diário de água. Verificou-se que o sistema de plantio direto reduziu a densidade e a massa seca das plantas daninhas em relação ao plantio convencional e a interferência destas reduziu a produtividade comercial em ambos os sistemas de cultivo. O tratamento com capinas nos sistema de plantio direto, apesar do maior consumo de água, apresentou produtividade e eficiência no uso da água superior aos tratamentos com filme de polietileno nos sistemas de plantio direto e convencional e o capinado no plantio convencional.

Palavras-chave: Pimentão. Planta e água. Cobertura morta. Planta daninha - controle.

\footnotetext{
*Autor para correspondência

Recebido para publicação em 15/03/2012; aprovado em 13/03/2013

Tese de Doutorado da primeira autora apresentada ao Programa de Pós-Graduação em Fitotecnia da Universidade Federal Rural do Semi-Árido, Mossoró-RN, pesquisa financiada pelo CNPq e pela CAPES DINTER

${ }^{2}$ Instituto Federal de Educação, Ciência e Tecnologia do Ceará/IFCE, Campus Iguatu, Iguatu-CE, Brasil, mehcoelho@ yahoo.com.br

${ }^{3}$ Universidade Federal Rural do Semi-Árido/UFERSA, Mossoró-RN, Brasil, fclaudiof @yahoo.com.br, jfmedeir@ufersa.edu.br, m_gledson@ yahoo.com.br

${ }^{4}$ Universidade Federal de Alagoas, Maceió-AL, Brasil, jorge.cunha.xavier@gmail.com
} 


\section{INTRODUCTION}

The green pepper (Capsicumn annuum L.) belongs to the solanaceous family of plants and is among the five vegetables with the greatest cultivated area, both in Brazil and around the world (MOREIRA et al., 2008). The Brazilian northeast presents favourable climatic conditions for its cultivation throughout the year (SILVA et al., 2010). The water supply however is seen as a limiting factor in its implementation, especially in the semi-arid region. This water supply, both quantitatively due to drought as a result of low rainfall coupled with the high potential for water loss through evapotranspiration, and qualitatively, since much of the semi-arid region is of soils having problems of salinity, where the unsuitable usage of water with high concentrations of salts possibly further aggravates the situation.

Several studies have recently been developed to promote the rational use of water in agriculture (MAROUELLI etal., 2010; SOUZAetal., 2011;TEÓFILO et al., 2012). The association of the use of efficient irrigation methods, such as drip irrigation employing a suitable volume of water, has been shown to increase the efficiency of water usage, providing suitable conditions for optimum plant development and higher productivity (TEÓFILO et al., 2012; VIANA et al., 2007).However, beyond the effective control of the volume applied in irrigation, the adoption of mechanisms that may promote greater efficiency in water usage is fundamental to raising the water-retention capacity of the soil by increasing infiltration and reducing evaporation and surface runoff. The reduction of water loss through evaporation can be achieved by such strategies as mulching with inorganic material, such as polyethylene film, or with organic material of vegetable origin (TEÓFILO et al., 2012). A ground cover of plant material (straw) is one of the principles on which the no-tillage system is based, as well as not turning the soil and of crop rotation.

The efficiency of the no-tillage system in reducing water consumption has been verified in tomato crops (MAROUELLI; SILVA; WOOD, 2006), cabbage (MAROUELLI et al., 2010), green pepper (SOUZA et al., 2011) and melon (TEÓFILO et al., 2012). According Teófilo et al. (2012), this economy is more significant in the initial stages of the crop cycle due to the higher water loss through evaporation.

Another benefit found in areas where a no-tillage system is employed, is the reduction of infestation by weeds (MATTHEW; CRUSCIOL; NEGRISOLI, 2004; TREZZI; VIDAL, 2004) which compete with the crop for water, light and nutrients, and which is reflected in the quantitative and qualitative reduction in productivity, besides increasing operating costs (TEÓFILO et al., 2012).
A second strategy that has been used to control weeds and reduce water loss through evaporation in the cultivation of vegetables is ground cover with polyethylene film (SILVA, 2010), it is however a technique that has a high cost in raw materials and the manpower needed to lay the material in the field.

The objective of the present work was to evaluate the efficiency of water usage in the green pepper under no-tillage and conventional systems and with different strategies for weed management.

\section{MATERIAL AND METHODS}

The experiment was conducted in the educational market garden of the Department of Plant Sciences at the Universidade Federal do Rural do Semi-Árido (UFERSA) in the town of Mossoró, Rio Grande do Norte, Brazil, which is located at $5^{\circ} 11^{\prime} \mathrm{S}$ and $37^{\circ} 20^{\prime}$ $\mathrm{W}$ and is at an altitude of $18 \mathrm{~m}$. The climate of the region, according to the Köppen classification, is of the BSwh" type, hot and dry, with an average annual rainfall of $673.9 \mathrm{~mm}$, and temperature and relative humidity averages of $27{ }^{\circ} \mathrm{C}$ and $68.9 \%$ respectively. The rainy season in the region is from February to June, with very low chance of rainfall between August and December (CARMO FILHO; OLIVEIRA, 1995).

A split-lot scheme was used, distributed in an experimental design of randomised blocks, with four replications. The no-tillage (NTS) and conventional tillage (CTS) systems were evaluated in lots from areas previously cultivated under the respective systems for four years. The sub-lots consisted of three strategies of weed management (soil cover with black polyethylene film, regular weeding and no weeding). Each experimental unit consisted of three rows of $12 \mathrm{~m}$, spaced $0.90 \mathrm{~m}$ apart, with plants in the rows spaced $0.60 \mathrm{~m}$ apart. The central row without the two plants at each end was considered as the usable area in the experiment.

In order to obtain the straw for the no-tillage treatments, maize intercropped with Brachiaria brizanta cv. "Marandu" was planted in February 2010, as soon as the rainy season began. Sowing of the forage mixed with fertiliser was carried out in the corn rows. After the corn harvest in late May, the forage was free to grow until July, when drying took place using $1.9 \mathrm{~kg} \mathrm{ha}^{-1}$ of glyphosate herbicide to produce straw, which was quantified by taking samples, and found to have a dry weight of $6.0 \mathrm{t} \mathrm{ha}^{-1}$.

In those plots under conventional tillage, the area was also planted with maize at the same time and the soil prepared by one ploughing and two harrowings, carried out a week before transplanting the green pepper seedlings. The 
experiment was implemented on 2 September 2010 with transplanting of the seedlings which had been produced in expanded polystyrene trays of 200 cells. The green-pepper hybrid Atlantis was used in the experiment.

Soil samples for each tillage system were taken from the area where the experiment was carried out, at depths of 0 and $20 \mathrm{~cm}$, for chemical and physical analysis. The soil was classified as a eutrophic Red-Yellow Argisol presenting the following particle size distribution: total sand $=$ dag $\mathrm{kg}^{-1}$; silt $=8 \mathrm{dag} \mathrm{\textrm {kg } ^ { - 1 }}$; clay $=3 \mathrm{dag} \mathrm{kg}{ }^{-1}$, while the chemical analyses of the soil gave the following results for the no-tillage system: $\mathrm{pH}$ (water) $=6.2$; organic matter $=12.8 \mathrm{~g} \mathrm{~kg}^{-1} ; \mathrm{P}=127 \mathrm{mg} \mathrm{dm}{ }^{-3} ; \mathrm{K}^{+}=160 \mathrm{mg} \mathrm{dm}{ }^{-3} ; \mathrm{Ca}^{2+}$ $=3.40 \mathrm{cmol}_{\mathrm{c}} \mathrm{dm}^{-3} ; \mathrm{Mg}^{2+}=1.05 \mathrm{cmol}_{\mathrm{c}} \mathrm{dm}^{-3} ; \mathrm{Al}^{3+}=0.10$ $\mathrm{cmol}_{\mathrm{c}} \mathrm{dm}^{-3}$ and for the conventional system: $\mathrm{pH}$ (water) $=$ 6.1 ; organic matter $=10.1 \mathrm{~g} \mathrm{~kg}^{-1} ; \mathrm{P}=260 \mathrm{mg} \mathrm{dm}{ }^{-3} ; \mathrm{K}^{+}=$
$157 \mathrm{mg} \mathrm{dm}{ }^{-3}, \mathrm{Ca}^{2+}=3.65 \mathrm{cmol}_{\mathrm{c}} \mathrm{dm}^{-3} ; \mathrm{Mg}^{2+}=0.90 \mathrm{cmol}_{\mathrm{c}}$ $\mathrm{dm}^{-3} ; \mathrm{Al}^{3+}=0.075 \mathrm{cmol}_{\mathrm{c}} \mathrm{dm}^{-3}$.

Data on daily maximum, minimum and average air temperatures, wind speed at 2.0 metres, solar radiation, reference evapotranspiration(ETo) estimated by employing the Penmam Motheith equation parameterized by the FAO (ALLEN et al., 2006), rainfall indices and air humidity for the period of the experiment, are shown in Figure 1.

Fertilization by fertigation was carried out based on the chemical analysis of the soil and on crop requirements, using $200.0 \mathrm{~kg} \mathrm{ha}^{-1} \mathrm{~N}, 300 \mathrm{~kg} \mathrm{ha}^{-1}$ of $\mathrm{P}_{2} \mathrm{O}_{5}$ and $250.0 \mathrm{~kg} \mathrm{ha}^{-1}$ $\mathrm{K}_{2} \mathrm{O}$ in the form of ammonium sulphate, mono-ammonium phosphate (MAP) and potassium chloride respectively.

Cultivation practices consisted of hand weeding, in those treatments with weeding, and spraying

Figure 1 - Average, maximum and minimum air temperature (A), wind speed (2 meters), solar radiation and reference evapotranspiration (ETo) (B), precipitation (C) and air humidity (D) for the period of the experiment. Mossoró RN, UFERSA, 2010/2011
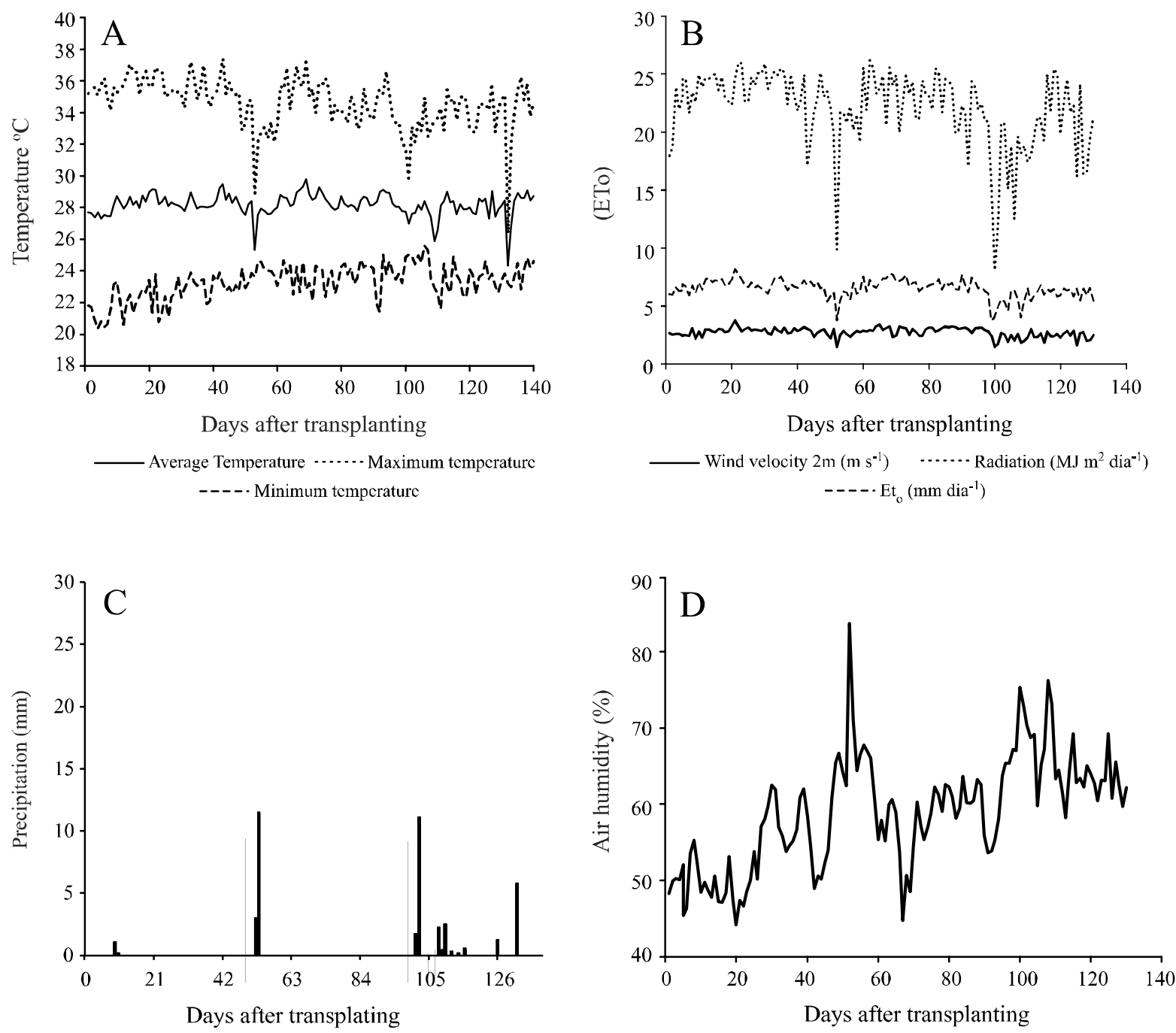
with fungicides and insecticides as required through observations conducted in loco. The plants were trained using wooden posts and flat packthread. At the end of each row and every 2.0 meters a post was placed, and when the plants began to bloom, polyethylene packthread was double zigzagged back and forth between the plants, $15 \mathrm{~cm}$ above the ground. The process was repeated every $30 \mathrm{~cm}$ until the end of the crop cycle in such a manner as to enfold the plants.

The crop was drip-irrigated with emitters of $1.7 \mathrm{~L} \mathrm{~h}^{-1}$ spaced $0.30 \mathrm{~m}$ apart. Irrigation was carried out based on the soil water characteristic curve for each crop system, at depths of 15 and $30 \mathrm{~cm}$, in order to maintain the soil humidity at more than $80 \%$ of the total available water. Control of water volume was based on daily readings of two tensiometers installed at the same depths as the soil water characteristic curve, and for each treatment the soil humidity was raised to values corresponding to the average matric potential at the two depths (about $-3 \mathrm{kPa}$, equivalent to the matric potential at field capacity). Based on this information of the volumes of water applied, the daily water consumption was determined every fortnight for the different periods of green-pepper cultivation under each treatment, and water consumption was evaluated taking this fortnightly daily average.

To determine the temperature of the soil, copper constantan thermocouples were installed at a depth of $5 \mathrm{~cm}$ in each sub-lot, wrapped in polyethylene microtubing to prevent oxidation of the thermocouple. Data were collected every 10 minutes and stored in Campbell CR1000 data loggers.

At $21 ; 42 ; 63 ; 84 ; 105$ and 126 days after transplanting, the weeds were evaluated in those treatments with no weeding, by means of two samples per sub-lot taken from cleared areas of $0.50 \mathrm{~cm}$ per side. The weeds were separated by species, counted and put into a forced-air oven at $65^{\circ} \mathrm{C}$ until reaching constant weight, when assessments of population density and dry weight of the weeds was carried out.

Plants were harvested weekly from 5 November 2010 to 17 January 2011 in the usable area of the sub-lot. The fruits after harvesting were classified into commercial and non-commercial, being considered as marketable those fruits with a length of over $6.0 \mathrm{~cm}$ and free of blemishes, lesions and deformities. Data were converted into commercial productivity $\left(\mathrm{t} \mathrm{ha}^{-1}\right)$ and total productivity $\left(\mathrm{t} \mathrm{ha}^{-1}\right)$.

From the total fruit yield $(\mathrm{Pt}, \mathrm{t}$ ha-1) and the amount of water applied through irrigation during the crop cycle for each treatment $\left(\mathrm{W}, \mathrm{m}^{3} \mathrm{ha}^{-1}\right)$, the water usage efficiency was determined (WUE, $\mathrm{kg} \mathrm{m}^{-3}$ ), as described by Doorenbos and Kassam (1979):

$W U E=P t / W$
The data were subjected to variance analysis and the treatment averages compared by Tukey test at 5\% significance. Water consumption during the cycle underwent regression analysis. In choosing the model the biological explanation and the significance of the mean square (regression) and of the parameter estimates, were all taken into account.

\section{RESULTS AND DISCUSSION}

Among the cropping systems, the lowest density of weeds throughout the crop cycle of the green pepper was seen under NT, which was probably due to the unturned soil and the physical effects of the straw inhibiting the emergence of invasive plants (Figure 2). Several other studies also showed a lower incidence of weeds under a no-tillage system (TEÓFILO et al., 2012; SILVA, 2010). The main species of weed present were amaranto (Talinum paniculatum), pigweed (Amaranthus spinosus), scarlet starglory (Merremia aegyptia), watergrass (Digitaria bicornis), nutsedge (Cyperus rotundus), tropical spiderwort (Commelina benghalensis), lobe croton (Croton lobatus), balsam pear (Momordica charantia), burr grass (Cenchuse echinatus) and high mallow (Malva sylvestris).

The largest population of weeds under CT was observed at 21 days after transplanting, with 520 plants $\mathrm{m}^{-2}$, decreasing thereafter until the end of the cycle (Figure 2). This reduction is due to interand intraspecific competition between the species of weed and the crop itself, considering that with the greater number of weeds per unit area, the more competitive and larger individuals become dominant and occupy space, and the smallest are removed or die (RADOSEVICH HOLT; GHERSA, 1996), this being due to the restriction on photosynthetically active light for the smaller plants (SILVA, 2010).

The dry mass of the invasive species showed an increase until approximately 63 and 84 days after transplanting under CTS and NTS respectively followed by a decline, reaching similar results for both systems at 126 DAT (Figure 2). The high increase in the dry mass of weeds under NT, which was due, even at low density (Figure 2), to the predominance of some larger species like starglory, balsam pear and lobe croton offsetting the lower density by accumulating a greater amount of dry matter per plant.

The presence of weeds in those treatments with no weeding under the two planting systems, caused intense shading of the soil, reducing its heating even during the hottest hours of the day and resulting in lower 
Figure 2 - Density (A) and dry weight (B) of weeds during the cycle of the green peppers as a function of the cropping systems and plant-management strategies. Mossoró RN, UFERSA, 2010/2011
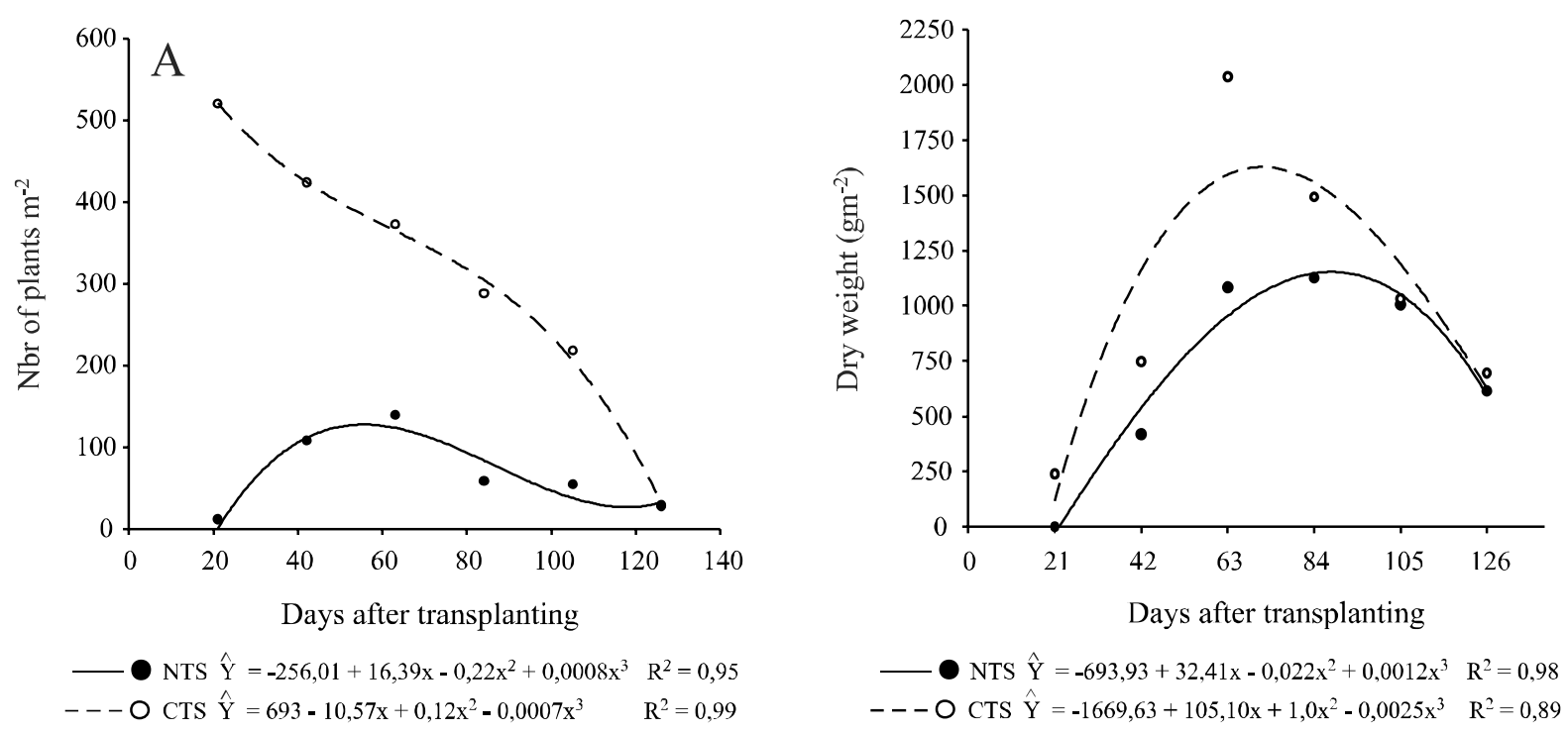

Figure 3 - Maximum (A) and minimum (B) daily soil temperatures during the crop cycle of the green pepper as a function of weed-management strategies and soil cover under no-tillage (NTS) and conventional tillage (CTS) systems. Mossoró RN, UFERSA, 2010/2011
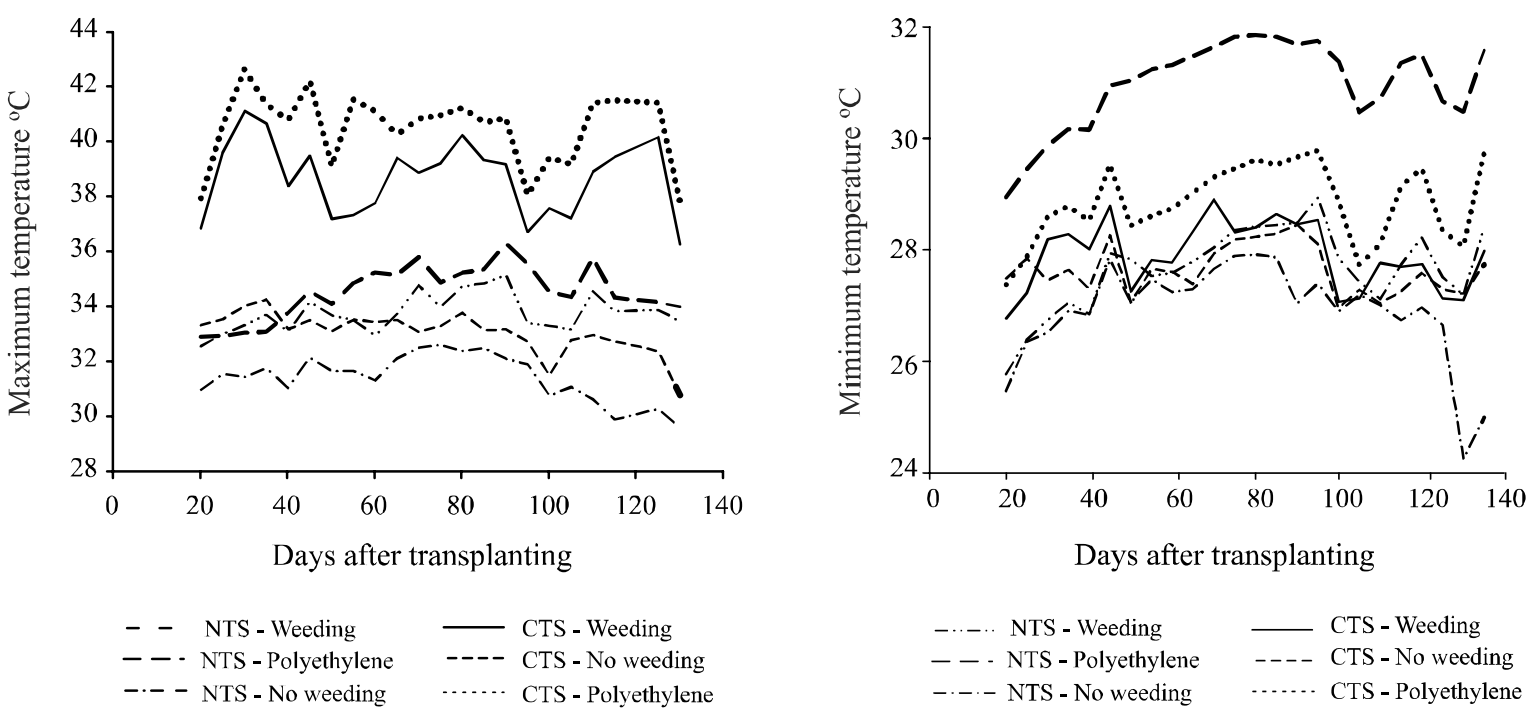

maximum and minimum temperatures throughout the cycle of the green pepper (Figure 3).

In those treatments with no weeding, under both tillage systems water consumption was higher compared to the other treatments due to transpiration of the invasive plants, until near the end of the cycle when the process of senescence begins, showing that the invasive plants demanded large amounts of water (Figure 4), resulting

in competition with the crop should the supply of water be limited. To avoid competition for water between the invasive plants and the green-pepper crop, soil humidity was kept above $80 \%$ of the available water.

The greatest water consumption due to the presence of weeds was found by Procópio et al. (2004), who found that the species Bidens pilosa (Spanish needle) and Euphorbia heterophylla (mole plant) showed a greater 
Figure 4 - Daily consumption of water (two weeks after transplanting) during the crop cycle of the green pepper, as a function of no-tillage (NTS) and conventional tillage (CTS) systems and strategies for weed management. Mossoró RN, UFERSA, 2010/2011

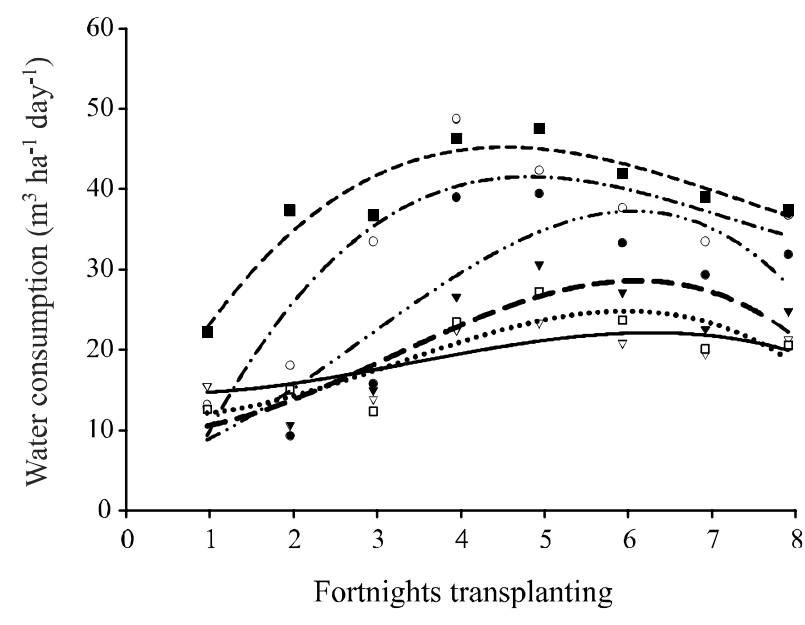

- NTS - Weeding $\hat{Y}=6,54+1,85 x+1,86 x^{2}-0,22 x^{3} \quad R^{2}=0,85$ - O NTS - No weeding $\hat{Y}=-12,07+26,57 x-4,1 x^{2}+0,19 x^{3} \quad R^{2}=0,91$ - NTS - Polyethylene $\hat{Y}=11-0,80 x+1,68 x^{2}-0,18 x^{3} \quad R^{2}=0,88$ $\nabla$ CTS - Weeding $\hat{Y}=19,84-3,52 x+1,33 x^{2}-0,11 x^{3} \quad R^{2}=0,70$ CTS - No weeding $\hat{Y}=6,71+19,78 x-3,12 x^{2}+0,14 x^{3} \quad R^{2}=0,95$ …… $\square$ CTS - Polyethylene $\hat{Y}=13,34-1,39 x+1,46 x^{2}-0,15 x^{3} \quad R^{2}=0,84$

efficiency in water usage in the early stages of growth, in relation to soy and beans. Dalley, Barnards and Kells (2006), working with maize, observed a higher efficiency of water usage and absorption by the weeds. Araldi et al. (2011) noted that the weeds Digitaria bicornis (watergrass), Panicum maximum (Guinea grass) and Ipomoea grandifolia (morning-viola), consumed more water per $\mathrm{cm}^{2}$, and showed a greater competitiveness for water, than sugarcane plants. Teófilo et al. (2012) observed in a crop of melon, increased water consumption in treatments with no weeding compared to those with weeding, due to the growth of large invasive species such as Amaranthus spinosus (pigweed) and Merremia aegyptia (starglory).

Comparing strategies for weed control, it was found that all curves adjusted to the cubic polynomial model, showing increasing water consumption under the two planting systems until about the fifth fortnight (Figure 4), probably due to environmental conditions and the increase in leaf area of the crop creating an increase in the rate of evapotranspiration.

In investigating the interactions of the soiltillage systems and weed-management strategies during the crop cycle of the green pepper (Table 1), it was observed in treatments with no weeding, that
NTS showed a $50 \%$ reduction in water consumption in relation to CTS up until the second fortnight, due to lower weed infestation, and from the third week no significant difference was seen between the planting systems. This is due to the increase in water consumption under NTS, caused by infestation by larger species such as starglory and balsam pear, which even at low density promoted an intense accumulation of dry mass (Figure 2). Throughout the crop cycle, CTS with no weed management increased water consumption by $20.20 \%\left(813.30 \mathrm{~m}^{3} \mathrm{~h}^{-1}\right)$ compared to SPD (Table 1).

When using polyethylene film no difference in water consumption was seen between the two tillage systems (Table 1), despite CTS, which employs turning of the soil, presenting an increase of $5{ }^{\circ} \mathrm{C}$ in the daily maximum temperature of the soil in comparison to NTS (Figure 3).

When regular weeding was carried out on the crop throughout its cycle, it was found that NTS reduced water consumption in the first two fortnights with respect to CTS (Table 1). This was due to the effect of the straw covering the soil, employed in SPD, because of its being a physical barrier, reducing the rate of evaporation and preventing the incidence of solar radiation and, as a consequence, lowering soil warming at the hottest time of the day by up to $7^{\circ} \mathrm{C}$ (Figure 3 ) as well as reducing the loss of water as vapour. Medeiros (2007) found that mulch on the soil can promote a reduction in water consumption to the order of 50 to $70 \%$ in the initial phase of the crop, due to reducing direct evaporation from the soil.

From the third week, higher water consumption was seen under NTS because of the increased plant growth and higher productivity of the green pepper under this treatment compared to CTS (Table 1).

The greatest consumption of water under NTS with weeding seen in this work differs from the results seen by Marouelli et al. (2010) and Teófilo et al. (2012) who found a lower consumption under NTS during the crop cycle. However, these authors found similar plant growth under both tillage systems, with the saving being due to a reduction in the rate of evaporation due to the straw. In this work, the greater consumption of water under NTS was probably due to a larger loss of water through transpiration as a result of the greater growth of the plants.

When comparing strategies for weed management within the cropping systems, under NTS a greater total water consumption is seen in those treatments with no weeding compared to those employing polyethylene film, and not differing from those treatments with weeding (Table 1). The lower water consumption in the treatment with polyethylene film in relation to that where the ground is covered with straw, is due to a lower water consumption through transpiration, which is in turn due 
Table 1 - Daily water consumption $\left(\mathrm{m}^{3} \mathrm{ha}^{-1}\right)$ at different growth stages (fortnight) and total water consumption of the green pepper $\left(\mathrm{m}^{3} \mathrm{ha}^{-1}\right)$ as a function of weed-management strategies under no-tillage (NTS) and conventional tillage (CTS) systems. Mossoró RN, UFERSA, 2010/2011

\begin{tabular}{lcccccccccc}
\hline Tillage & Management & \multicolumn{1}{c}{ Daily consumption $\left(\mathrm{m}^{3} \mathrm{ha}^{-1}\right.$ dia $\left.^{-1}\right)$ Periods (Fortnights) } & \multicolumn{2}{c}{ Total consumption } \\
\hline system & System & 1 & 2 & 3 & 4 & 5 & 6 & 7 & 8 & $\left(\mathrm{~m}^{3} \mathrm{ha}^{-1}\right)$ \\
\hline \multirow{3}{*}{ NTS } & Polyethylene & $13.7 \mathrm{aA}$ & $11.8 \mathrm{bA}$ & $16.0 \mathrm{bA}$ & $27.3 \mathrm{bA}$ & $30.9 \mathrm{aA}$ & $27.8 \mathrm{bA}$ & $23.4 \mathrm{bA}$ & $25.5 \mathrm{bA}$ & $2658.8 \mathrm{bA}$ \\
& Weeding & $13.7 \mathrm{aB}$ & $10.5 \mathrm{bB}$ & $16.8 \mathrm{bA}$ & $39.3 \mathrm{bA}$ & $39.7 \mathrm{aA}$ & $33.7 \mathrm{bA}$ & $29.9 \mathrm{bA}$ & $32.4 \mathrm{bA}$ & $3243.9 \mathrm{abA}$ \\
& No Weeding & $14.2 \mathrm{aB}$ & $18.9 \mathrm{aB}$ & $33.9 \mathrm{aA}$ & $48.7 \mathrm{aA}$ & $42.0 \mathrm{aA}$ & $37.9 \mathrm{aA}$ & $33.9 \mathrm{aA}$ & $37.1 \mathrm{aA}$ & $4013.9 \mathrm{aB}$ \\
\hline Mean & & 13.90 & 13.76 & 22.24 & 38.42 & 37.52 & 33.18 & 29.06 & 31.66 & 3305.53 \\
\hline \multirow{2}{*}{ CTS } & Polyethylene & $13.7 \mathrm{cA}$ & $16.1 \mathrm{bA}$ & $13.5 \mathrm{bA}$ & $24.2 \mathrm{bA}$ & $27.7 \mathrm{bA}$ & $24.5 \mathrm{bA}$ & $20.1 \mathrm{bA}$ & $21.4 \mathrm{bA}$ & $2700.8 \mathrm{bA}$ \\
& Weeding & $18.5 \mathrm{bA}$ & $16.5 \mathrm{bA}$ & $14.9 \mathrm{bA}$ & $23.3 \mathrm{bB}$ & $24.1 \mathrm{bB}$ & $21.7 \mathrm{bA}$ & $20.4 \mathrm{bA}$ & $22.1 \mathrm{bB}$ & $2618.2 \mathrm{bB}$ \\
& No Weeding & $23.0 \mathrm{aA}$ & $37.7 \mathrm{aA}$ & $37.1 \mathrm{aA}$ & $48.1 \mathrm{aA}$ & $47.6 \mathrm{aA}$ & $42.2 \mathrm{aA}$ & $39.3 \mathrm{aA}$ & $37.7 \mathrm{aA}$ & $4827.2 \mathrm{aA}$ \\
\hline Mean & & 18.41 & 23.44 & 21.83 & 31.87 & 33.12 & 29.44 & 26.88 & 27.07 & 3382.06 \\
\hline CV $(\%)$ & & 7.71 & 20.96 & 24.18 & 17.12 & 18.80 & 21.69 & 21.47 & 16.67 & 15.96 \\
\hline
\end{tabular}

In the columns, lower-case letters compare weed-management strategies within each tillage system and upper-case letters compare tillage systems by theTukey test at $5 \%$ significance $(p=0,005)$

Table 2 - Mean values of total dry matter (TDM) throughout the crop cycle of the green pepper as a function of weedmanagement strategies under no-tillage and conventional tillage systems. Mossoró RN, UFERSA, 2010/2011

\begin{tabular}{lccccccccc}
\hline \multicolumn{10}{c}{ Total dry matter $\left(\mathrm{g}\right.$ plant $\left.{ }^{-1}\right)$} \\
\hline Tillage system & Management system & 0 DAT & $21 \mathrm{DAT}$ & $42 \mathrm{DAT}$ & $63 \mathrm{DAT}$ & $84 \mathrm{DAT}$ & $105 \mathrm{DAT}$ & $126 \mathrm{DAT}$ & $147 \mathrm{DAT}$ \\
\hline \multirow{3}{*}{ No-tillage } & Polyethylene & $0.21 \mathrm{aA}$ & $0.71 \mathrm{aA}$ & $5.35 \mathrm{aA}$ & $24.02 \mathrm{aA}$ & $52.39 \mathrm{bA}$ & $86.99 \mathrm{bA}$ & $145.16 \mathrm{bA}$ & $81.01 \mathrm{bA}$ \\
& Weeding & $0.19 \mathrm{aA}$ & $0.48 \mathrm{aA}$ & $4.84 \mathrm{aA}$ & $31.09 \mathrm{aA}$ & $83.85 \mathrm{aA}$ & $166.94 \mathrm{aA}$ & $286.48 \mathrm{aA}$ & $247.83 \mathrm{aA}$ \\
& No weeding & $0.19 \mathrm{aA}$ & $0.64 \mathrm{aA}$ & $3.84 \mathrm{aA}$ & $12.08 \mathrm{bA}$ & $24.87 \mathrm{cA}$ & $39.76 \mathrm{cA}$ & $26.56 \mathrm{cA}$ & $16.82 \mathrm{cA}$ \\
\hline \multirow{2}{*}{ Conventional } & Polyethylene & $0.17 \mathrm{aA}$ & $0.52 \mathrm{aA}$ & $2.94 \mathrm{aB}$ & $12.47 \mathrm{aB}$ & $18.65 \mathrm{aB}$ & $34.54 \mathrm{aB}$ & $61.62 \mathrm{bB}$ & $49.97 \mathrm{bA}$ \\
Tillage & Weeding & $0.17 \mathrm{aA}$ & $0.62 \mathrm{aA}$ & $2.37 \mathrm{aB}$ & $10.24 \mathrm{aB}$ & $18.75 \mathrm{aB}$ & $34.51 \mathrm{aB}$ & $90.93 \mathrm{aB}$ & $74.54 \mathrm{aB}$ \\
& No weeding & $0.17 \mathrm{aA}$ & $0.71 \mathrm{aA}$ & $0.89 \mathrm{bB}$ & $3.87 \mathrm{bB}$ & $10.04 \mathrm{bB}$ & $11.07 \mathrm{bB}$ & $8.72 \mathrm{cA}$ & $1.80 \mathrm{cA}$ \\
\hline $\mathrm{CV}(\%)$ & & 21.34 & 30.99 & 32.90 & 36.91 & 45.32 & 33.23 & 37.09 & 42.81 \\
\hline
\end{tabular}

In the columns, lower-case letters compare weed-management strategies within each tillage system and upper-case letters compare tillage systems by theTukey test at $5 \%$ significance

to the lower vegetative growth (Table 2), also resulting in lower productivity (Table 3 ) because of the effect of the straw acting as a thermal insulator on the polyethylene film and, although avoiding the excessive rise in daytime temperature, also preventing it from decreasing overnight, keeping the soil at between 30 and $32{ }^{\circ} \mathrm{C}$ (Figure 3). Coelho (2011) working with the cultivation of green pepper in the open, found that soil temperatures over $30{ }^{\circ} \mathrm{C}$ significantly reduced the development of the green pepper plants, also reducing the number of fruits per plant. According Padua, Casali and Pinto (1984), soil temperatures over $30{ }^{\circ} \mathrm{C}$ impair the vegetative and reproductive growth of the green pepper crop.

Under CTS the largest water consumption for the complete the crop cycle occurred under the treatment with no weeding, due to the heavy infestation by weeds. Teófilo et al. (2012) also found an increase in water consumption in melon crops due to weed infestation. Under the treatments with polyethylene film and weeding, the lower water consumption is due to the smaller growth of the green pepper plants (Table 2), which was probably because of the intense rise in the daily maximum temperature, that reached 42 and $40{ }^{\circ} \mathrm{C}$ respectively.

For those characteristics related to commercial productivity and total fruit, there was a significant effect of the interaction between the tillage systems and the weed-management strategies (Table 3 ). The no-tillage system with weeding, presented both marketable and total fruit yields superior to those under conventional 
Table 3 - Total and commercial productivity $\left(\mathrm{t} \mathrm{ha}^{-1}\right)$ and water-usage efficiency $\left(\mathrm{kg} \mathrm{m}^{-3}\right)$ in the green pepper crop as a function of weedmanagement strategies under no-tillage (NTS) and conventional tillage (CTS) systems. Mossoró RN, UFERSA, 2011

\begin{tabular}{|c|c|c|c|c|c|}
\hline \multirow[t]{2}{*}{ Tillage system } & \multirow{2}{*}{ system } & \multirow{2}{*}{ productvity } & \multirow{2}{*}{ productivity } & $\begin{array}{l}\text { Water-usage } \\
\text { efficiency }\end{array}$ & $\begin{array}{l}\text { Water-usage } \\
\text { efficiency }\end{array}$ \\
\hline & & & & comercial & Total \\
\hline \multirow{3}{*}{ NTS } & Polyethylene & $6.04 \mathrm{bA}$ & $10.42 \mathrm{bA}$ & $2.27 \mathrm{bA}$ & $4.01 \mathrm{bA}$ \\
\hline & Weeding & $36.28 \mathrm{aA}$ & $38.41 \mathrm{aA}$ & $11.18 \mathrm{aA}$ & $11.96 \mathrm{aA}$ \\
\hline & No weeding & $1.83 \mathrm{bA}$ & $1.93 \mathrm{cA}$ & $0.45 \mathrm{bA}$ & $0.51 \mathrm{cA}$ \\
\hline \multirow[t]{2}{*}{ Mean } & & 14.72 & 16.92 & 4.63 & 5.50 \\
\hline & Polyethylene & $7.06 \mathrm{aA}$ & $8.45 \mathrm{aA}$ & $2.61 \mathrm{aA}$ & $3.06 \mathrm{aA}$ \\
\hline \multirow[t]{2}{*}{ CTS } & Weeding & $9.86 \mathrm{aB}$ & $12.18 \mathrm{aB}$ & $3.76 \mathrm{aB}$ & $4.62 \mathrm{aB}$ \\
\hline & No weeding & $0.78 \mathrm{bA}$ & $0.78 \mathrm{bA}$ & $0.16 \mathrm{bA}$ & $0.17 \mathrm{ba}$ \\
\hline Mean & & 5.90 & 7.13 & 2.17 & 2.62 \\
\hline $\mathrm{CV} \%$ & & 25.71 & 22.67 & 27.65 & 28.46 \\
\hline
\end{tabular}

In the columns, lower-case letters compare weed-management strategies within each tillage system and upper-case letters compare tillage systems by theTukey test $(\mathrm{p}=0,05)$

tillage. When employing polyethylene film and no weeding, productivity was similar under both tillage systems.

Despite the higher water consumption (Figure 3 and Table 1), the treatment with weeding under NTS showed a higher yield compared to the other treatments evaluated, resulting in a more efficient usage of the water, as can be seen in Table 3. The greater efficiency in water usage $\left(11.86 \mathrm{~kg} \mathrm{~m}^{-3}\right)$ under NTS with regular weeding can be attributed to the effect of the straw acting as thermal insulation and reducing the soil temperature (Figure 2), and also to the absence of weeds. The results show that those systems which keep the soil covered reduce the maximum temperatures (SILVA; REICHERT; REINERT, 2006), with positive effects on the conservation of soil humidity (CARVALHO et al., 2011; MAROUELLI et al., 2010; SILVA; REICHERT; REINERT, 2006) and consequently higher production and greater efficiency in water usage.

Under the treatments with no weeding, besides increasing water consumption (Table 1), the weeds reduced the commercial and overall productivity, having a negative influence on the efficiency of water usage under both tillage systems (Table 3), demonstrating the interference of invasive plants through such factors as competition for light, nutrients and space and a probable allelopathic effect, since water was not a limiting factor. Teofílo et al. (2012) found in the melon crop that interference by weeds resulted in a reduction in productivity, an increase in water consumption and consequently a reduction in water usage efficiency.

Under both tillage systems, polyethylene film cover allowed for less water consumption compared to NTS with weeding (Table 1), but due to the low productivity, resulted in increased water consumption per kilogram of fruit produced. The same occurred in the management strategy employing weeding under CTS, which despite presenting the lowest water consumption of all the treatments, obtained an efficiency for water usage $67.37 \%$ lower than under NTS treatment with weeding (Table 3).

When comparing the two tillage systems for each strategy of weed management, it was found that NTS produced the most efficient usage of water under all strategies, especially for NTS with regular weeding, which is due to the combination of water economy and high productivity. More efficient water usage under NTS in relation to CTS was noted by Marouelli, Silva and Wood (2006) and Marouelli (2010) in the tomato, onion and cabbage; Carvalho et al. (2011) and Souza et al. (2011) in the green pepper; and Teófilo et al. (2012) in the melon. Resende et al. (2005) found that mulching, besides controlling weeds, increases the productivity of vegetable crops. Bezerra and Cantalice (2006) assert that the mulch makes water availabile to the plants, increasing the efficiency of its usage.

\section{CONCLUSION}

The no-tillage system with straw reduced the density and accumulated dry matter of weeds in comparison to the conventional tillage system. The treatment employing weeding under the no-tillage system showed higher productivity and a water-usage 
efficiency superior to those treatments where the soil was covered with polyethylene film, under both notillage and conventional tillage, and to weeding under conventional tillage. The no-tillage system with weeding is a viable alternative for increasing both productivity and water-usage efficiency in the green pepper.

\section{REFERENCES}

ALLEN, R. G. et al. Evapotranspiration del cultivo: Guías para la determinación de los requerimentos de agua de los cultivos. Roma: FAO, 2006. 298 p. (Estúdio FAO Riego y Drenaje, 56).

ARALDI, R. et al. Avaliação da absorção do amicarbazone e intoxicação em cana-de-açúcar e plantas daninhas. Planta daninha, v. 29, n. 4, p. 869-875, 2011.

BEZERRA, S. A.; CANTALICE, J. R. B. Erosão entre sulcos em diferentes condições de cobertura do solo, sob o cultivo da cana-de-açúcar. Revista Brasileira de Ciência do Solo, v. 30, n. 3 , p. $565-573,2006$.

CARMO FILHO, F. do; OLIVEIRA, O. F. de. Mossoró: um município do semiárido nordestino, caracterização climática e aspecto florístico. Mossoró: ESAM, 1995. 62 p. (Coleção Mossoroense, série B).

CARVAlHo, J. F. de. et al. Produtividade do repolho utilizando cobertura morta e diferentes intervalos de irrigação com água moderadamente salina. Revista Brasileira Engenharia Agrícola Ambiental, v. 15, n. 3, p. 256-263, 2011.

COELHO, M. E. H. Manejo de plantas daninhas sobre a temperatura do solo, eficiência no uso da água e crescimento da cultura do pimentão nos sistemas de plantio direto e convencional. 2011.108f. Tese (Doutorado em Fitotecnia) - Universidade Federal Rural do Semi-Árido - UFERSA Mossoró, 2011.

DALLEY, C. D.; BERNARDS, M. L.; KELLS, M. J. Effect of water removal timing and row spacing on soil moisture in corn (Zea mays). Weed Ecology, v. 20, n. 2, p. 399-409, 2006.

DOORENBOS, J.; KASSAM, A. H. Crop response to water. Roma: FAO, 1979. 194 p. (FAO, irrigation and Drainage Paper, 33).

MAROUELLI, W. A. et al. Eficiência de uso da água e produção de repolho sobre diferentes quantidades de palhada em plantio direto. Pesquisa Agropecuária Brasileira, v. 45, n. 4 , p. $369-375,2010$.

MAROUELLI, W. A.; SILVA, H. R.; MADEIRA, N. R. Uso de água e produção de tomateiro para processamento em sistema de plantio direto com palhada. Pesquisa Agropecuária Brasileira, v. 41, n. 9, p. 1399-1404, 2006.

MATEUS, G. P.; CRUSCIOL, C. A. A. C.; NEGRISOLI, E. Palhada do sorgo de guiné gigante no estabelecimento de plantas daninhas em área de plantio direto. Pesquisa Agropecuária Brasileira, v. 39, n. 6, p. 539-542, 2004.

MEDEIROS, J. F. Uso racional e preservação de recursos hídricos na agricultura. In: al. SIMPÓSIO SOBRE MANEJO DE PLANTAS DANINHAS NO SEMI-ÁRIDO. 2007, MossoróRN. Anais... Mossoró, 2007. p. 35-52.

MOREIRA, M. A. et al. Produção de mudas de pimentão com o uso de pó de coco. Revista da Fapese, v. 4, n. 2, p. 19-26, 2008.

PÁDUA J. G; CASALI V. W. D; PINTO C. M. F. Efeitos climáticos sobre pimentão e pimenta. Informe Agropecuário, v. 10, n. 13 , p. 11-13, 1984.

PROCÓPIO, S. O. et al. Características fisiológicas das culturas de soja e feijão e de três espécies de plantas daninhas. Planta Daninha, v. 22, n. 2, p. 211-216, 2004.

RADOSEVICH, S.; HOLT, J.; GHERSA, C. Physiological aspects of competition. In: RADOSEVICH, S.; HOLT, J.; GHERSA, C. Weed ecology implications for manegements. New York: John Willey \& Sons, 1996. p. 217-301.

RESENDE, F. V. et al. Uso de cobertura morta vegetal no controle da umidade e temperatura do solo, na incidência de plantas invasoras e na produção da cenoura em cultivo de verão. Ciência Agrotécnica, v. 29, n. 1, p. 100-105, 2005.

SILVA, P. I. B. et al. Crescimento de pimentão em diferentes arranjos espaciais. Pesquisa Agropecuária Brasileira, v. 45, n. 2, p. 132-139, 2010.

SILVA, V. R da; REICHERT, J. M; REINERT, D. J. Variação na temperatura do solo em três sistemas de manejo na cultura do feijão. Revista Brasileira Ciência Solo, v. 30, n. 3, p. 391-399, 2006.

SILVA, M. G. O. da. Cultivo da melancia nos sistemas de plantio direto e convencional. 2010. 50 f. Dissertação (Mestrado em Fitotecnia) - Universidade Federal Rural do Semi-Árido - UFERSA, Mossoró, 2010.

SOUZA, A. P. de. et al. Evapotranspiração, coeficientes de cultivo e eficiência do uso da água da cultura do pimentão em diferentes sistemas de cultivo. Acta Scientiarum Agronomy, v. 33, n. 1, p. 15-22, 2011.

TEÓFILO, T. M. da S. et al. Eficiência no uso da água e interferência de plantas daninhas no meloeiro cultivado nos sistemas de plantio direto e convencional. Planta Daninha, v. 30, n. 3, p. 547-556, 2012.

TREZZI, M. M.; VIDAL, R. A. Potencial de utilização de cobertura vegetal de sorgo e milheto na supressão de plantas daninhas em condições de campo: II - Efeitos da cobertura morta. Planta Daninha, v. 22, n. 1, p. 1-10, 2004.

VIANA, T. V. de A. et al. Produtividade do meloeiro fertirrigado com potássio em ambiente protegido. Horticultura Brasileira, v. 25, n. 3, p. 460-463, 2007. 